\title{
Vertebrate fauna of the Toruń Valley
}

\author{
Andrzej Przystalski, Tomasz Brauze, Krzysztof Kasprzyk
}

Institute of Ecology and Protection of Environment, Department of Vertebrate Zoology,

Nicolaus Copernicus University, Gagarina 9, 87-100 Toruń, Poland, e-mail: przystalski@umk.pl

\begin{abstract}
Being a mosaic of miscellaneous habitats, the Torun Valley is a refuge for numerous species of animals, who find their shelter here, food and favourable places for reproduction. Countrywide, the Valley is also an important natural ecological corridor for those animals. Regarding this function, the Vistula River is of particular significance within the described area. This study presents species of wild animals from all taxonomic groups of vertebrates, which occur in the Torun Valley. Apart from the list and the total number of species in individual taxa of higher rank, short descriptions of habitat requirements were provided together with the information on changes in the population resources of some major species. More attention was devoted to species, which withdrew from this area, as well as to those which were subject to the process of restoration. More space in the text was also dedicated to those species of vertebrates, which occur in frequent mosaics of heaths, psammophilous grasslands and encroaching pine forests. In the paper, the attention was also directed to threats posed to fauna by a hydrotechnical investment undertaken on the Vistula River upstream from the city of Torun, as well as to the significance of Natura 2000 areas legislated in the Torun Valley for the protection of species and habitats.
\end{abstract}

Key words: species richness, rare species, protected species, ecological corridor, Natura 2000, invasive alien species, restoration of species, diversity of habitats, the Vistula River Valley.

\section{Introduction}

Most of the vertebrate species occurring in the ecosystems of the Torun Valley are legally protected; a considerable group is constituted by species that are rare and threatened with extinction (Przystalski \& Kasprzyk 1997; Przystalski 2004).

A very significant impact on the fauna of the Torun Valley is exerted by the Vistula River Valley and the adjacent forests. The Vistula River is a very important ecological corridor of the continental importance (Kajak 1993; Tomiałojć 1993; Chylarecki et al. 1995; Gacka-Grzesikiewicz 1995). The course of the Vistula River near Torun is latitudinal, which forms a peculiar intersection of corridors running from the south to the north and from the west (the Noteć River Valley) to the east (the Valleys of the Drwęca and Narew Rivers). This brings about the fact that the diversity of encountered fauna, particularly during migrations, is very high in this area. The aim of this paper is to present the species richness of vertebrates in the Torun Valley, according to individual taxonomic groups.

\section{Species diversity in taxonomic groups of vertebrates}

Tributaries of the Vistula River are the place where the river lamprey Lampetra fluviatilis reproduces. Adult river lampreys migrate upstream from the Baltic Sea to spawn in the rivers once in their lifetime. They spawn in river bends where their larvae develop for four years. The river lamprey is a species strictly and actively protected by law. It was also included in the Polish Red Book of Animals on the list of species threatened with extinction (Głowaciński 2001). 
Among fish species important for fishing in the Vistula River during the historical period, one should mention the common sturgeon Acipenser sturio. Sturgeons migrated in the spring to spawning grounds located in the Rivers of Dunajec, Raba, Wisłoka, San and Wisłok (Grabda 1968). At the beginning of the last century they were still fished in large numbers along the section between two towns - Torun and Dobrzyń - on the Vistula River. The last documented sighting of the common sturgeon in the Vistula River Valley was recorded in 1964 near Toruń (Żelechowska 1964). At present, the restoration programme for the Baltic sturgeon Accipenser oxyrinchus is being implemented in the Drwęca River.

Salmon Salmo salar was yet another species, which in the 1950s still migrated in the Vistula River (Żarnecki 1963; Bartel et al. 1984). Although the size of the salmon population had been gradually decreasing, the migrations of this species came to an end when the dam in Włocławek was built in 1968 (Jokiel \& Bartel 1983; Backiel 1993). After 1994, as part of salmon restoration, smolts were being released to the mouth of the Drwęca River. Fish tagging enabled to follow the rate of their growth and migration. It was found that they occur in large numbers in the Gulf of Gdańsk and in the southern area of the Baltic Sea. Positive effects of the species restoration were confirmed by fishing in the rivers (Bartel 2001).

Another species maintained mainly due to fry-stocking is the sea trout Salmo trutta m. trutta. Until the 1970s, two populations of sea trout entered the Vistula River - the winter and the summer one. The former, dominant in number, migrated to the Vistula River in winter and the spawning took place in the following season in its upper tributaries. The latter - the summer sea trout entered the Vistula River in the summer and after few months it began to spawn in the tributaries of the Lower Vistula (Żarnecki 1963, 1964). Migrations of the sea trout upstream the Vistula River came to an end when the dam was built near the town of Włocławek. The undertaken expensive works on smolt breeding and intensive fry-stocking enabled to preserve the population of the summer sea trout in the Vistula River.

The species, which disappeared from the Lower Vistula is zarte Vimba vimba. The direct cause was building the dam across the Vistula River in the town of Włocławek. At present zarte occurs in the Włocławek Reservoir where it developed a local migratory population.

In the Vistula and Noteć Rivers, as well as in their larger tributaries, the following species still live: ide Leuciscus idus, dace Leuciscus leuciscus, chub Leuciscus cephalus, catfish Silurus glanis, asp Aspius aspius, nase Chondrostoma nasus, less frequently barbel Barbus barbus and zope Abramis ballerus, schneider Alburnoides bipunctatus, roach Rutilus rutilus, stone loach Noemacheilus barbatulus, perch Perca fluviatilis, pikeperch Stizostedion lucioperca, European eel Anguilla anguilla and coming from North America - brown bullhead catfish Ictalurus nebulosus. The pecularity of the fish species composition in the Vistula River and the estuarine section of the Drwęca River is an occasionally recorded marine flatfish - European flounder Platichthys flesus. Three new species appeared in the Vistula River, new to fauna of the region: rotan, also known as Amur sleeper Perccottus glenii (Kakareko 1999), racer (goad) goby Neogobius gymnotrachelus and monkey goby Neogobius fluviatilis. They are Ponto-Caspian species, which penetrated into the drainage basin of the Vistula River through the Rivers of Dniepr and Prypeć, as well as through the Dnieper-Bug Channel (Danilkiewicz 1996, 1998).

Lakes of the Torun Valley are populated by common domestic fish. The species composition and resources of lakes depend on the size and the trophic type of a reservoir, as well as fishery and angling management. In all types of water bodies with average fertility, the following fish species occur: pike Esox lucius, tench Tinca tinca, carp Cyprinus carpio, bream Abramis brama, roach, crucian carp Carrasius carrasius, European eel Anguilla anguilla, burbot Lota fligths, pikeperch, perch. Among smaller forms with no economic significance, the following are common: gudgeon Gobio gobio, silver bream Blicca bjoerkna, bleak Alburnus alburnus, belica Leucaspius delineatus, rudd Scardinius erythrophthalmus, brown bullhead catfish Ictalurus nebulosus, ruffe Gymnocephalus cernua and threespined stickleback Gasterosteus aculeatus. In small water bodies, such as oxbow lakes, ponds, peat pits, the following are predominant: pike, tench, crucian carp and silver crucian carp Carrasius auratus gibelio, as well as weatherfish. The list is completed by Asian herbivorous fishes introduced in the mid-1960s - grass carp Ctenopharyngodon idella, silver carp Hypophthalmichthys molitrix, bighead carp Aristichthys nobilis and peled Coregonus peled. The following species are particularly noteworthy: schneider, spined loach Cobitis taenia and weatherfish Misgurnus fossilis included in the ichthyofauna protected within the framework of Natura 2000 areas.

Natural composition of ichthyofauna is modified by fishery management implemented by fish farms, as well as angling societies and unions. The range and size of fish crops and fry-stocking with native or alien species significantly influence the biodiversity of rivers and lakes. Waters of the Valley are stocked with fry of several fish species in different age classes, which allows to maintain the equilibrium of fish stock based on mechanisms of natural selection. Rivers are stocked with fry of such species as: salmon, sea trout, brown trout and ide. Crucian and silver crucian carps, pike, pikeperch, perch, tench, common whitefish, vendace, roach, catfish, bream, carp and European eel are released into rivers, lakes and ponds.

The Torun Valley together with flood areas from the Valley of the Vistula and Noteć Rivers play an important 
role in the preservation of diversity and resources of the lowland fauna of amphibians. It is a group of vertebrates, the reproduction success of which depends on the water availability. The life of amphibians is affected mainly by climatic factors, such as: air and water temperature, precipitation, air humidity and insolation. Equally important are edaphic factors and vegetation cover, as well as chemical compounds used in industry and agriculture, which change the $\mathrm{pH}$ of water and contaminate the surface soil layers.

Within the area of the Torun Valley there occur all amphibian species characteristic of the Polish Lowland - altogether 13 species. Among tailed amphibians (Caudata) in the described area, the common newt Triturus vulgaris occurs in the largest numbers. Its mating takes place in shallow, overgrown water bodies, particularly in the preserved fragments of oxbow lakes, peat pits, ponds and ditches. After mating, mature specimens disperse in alluvial forests, alder woods, willow thickets, meadows and grazing lands. Great crested newt Triturus cristatus is another species, which occurs in small numbers at several dispersed locations (Przystalski 2004). Among three species of toads, the common toad Bufo bufo occurs most commonly and in the largest numbers. The common toad mates in oxbow lakes, clay pits, ponds, as well as field and forest water bodies. After mating, the common toad dwells in gardens, arable crops, wet meadows and forests. The other two species, green toad Bufo viridis and especially Natterjack toad Bufo calamita occur in small numbers. Toads reproduce in shallow parts of oxbow lakes, ponds, particularly in field clay pits, fish ponds and places with stagnant water in gravel pits. The green toad is a species, which undertakes longdistance migrations in quest of water during the mating period. The Natterjack toad is a species, which copes well with arid environments, therefore it often mates in places with stagnant water within gravel pits. Tadpoles of this species have small dimensions of the body and thus a little amount of food in these nutrient-poor water bodies is sufficient for their successful reproduction. The common spadefoot toad Pelobates fuscus is a species of agricultural landscapes. Its natural biotope are arable crops on the soils, which retain moisture throughout the season. The spadefoot toad mates in all types of water bodies, into which it migrates in early spring. It is a nocturnal species and therefore, it is not a well known amphibian. The European fire-bellied toad Bombina bombina is a species at the risk of extinction. Throughout the entire period of its active life, it is connected with water and comes ashore in autumn, in quest of winter shelters. When frightened, the toad assumes a characteristic defensive position - it suddenly raises its limbs presenting the orange belly spots to an aggressor. The species name comes from the male sound, commonly known as croaking. The European fire-bellied toad populates small water reservoirs such as oxbow lakes, ponds, ditches and peat pits. Another amphibian - the European tree frog Hyla arborea is more and more rare, and its occurrence is highly dispersed. The harmonious shape of its body, long fingers expanded into adhesive toe pads (disks), bright green colouration of the dorsal part contrasting with golden iris of the eye; all the aforementioned features cause that the tree frog is probably the only amphibian species in Poland, which is not repellent to humans. Like all amphibians, the tree frog mates in the water. It chooses small water bodies with abundantly overgrown shores. It is able to migrate considerable distances to reach them. Rhythmically repeated, loud croaking of males resembles barking of a small dog. After the mating period, tree frogs can be encountered in alluvial forests along the Vistula River, along lake shores, on the edge of forests, in orchards and meadows.

Among frogs, two groups are distinguished, which differ from each other in colouration. The former group comprises dark brown forms, including the European common frog Rana temporaria occurring in wet meadows, alder woods and alluvial forests, as well as the moor frog Rana arvalis, most frequently encountered in meadows, but also in deciduous and mixed pine forests. Both species mate in early spring, gathering in shallow parts of water bodies, ditches and flood waters. During that time, dorsa of moor frogs' males turn into intense blue colour, caused by the concentration of lymph under the skin. After mating, both species disperse within a large area, occurring in all types of terrestrial environments of the valley and adjacent areas. The latter group comprises green frogs. In larger ponds, lakes and oxbow lakes, marsh frog Rana ridibunda occurs, which is the biggest tailless amphibian (Anura) in Europe. The body length of adult specimens can reach more than $15 \mathrm{~cm}$ and the body weight can exceed a quarter of a kilo. The Polish name of the species accurately reflects the mating sound of males, which during sunny days of May and June utter croaking sounds resembling the laughter. The distribution of Rana ridibunda is limited to local sites. It results from the environmental requirements of this species, which populates deep water reservoirs with a well developed zone of rushes. At present, the count of the marsh frog in the Polish Lowlands decreases. As indicated by observations, this amphibian evidently withdraws from field and farmstead ponds, where it has occurred to date (Przystalski 2000). Oxbow lakes in the Valley of the Vistula and Noteć Rivers are important places that guarantee the existence of this species. Among green frogs, the pool frog Rana lessonae is the most frequently occurring species, the biotope of which are all types of water reservoirs. Among green frogs one should also mention a natural, hybridogenetic hybrid of the aforementioned species - edible frog Rana esculenta. It occurs in similar types of water reservoirs, particularly in those connected with watercourses.

In the past three decades, a sudden drop in the count of amphibians was observed. Species such as the European 
fire-bellied toad, common spadefoot toad, European tree frog, Natterjack and green toads are threatened with extinction. Land reclamations, which brought about lowering of the groundwater level, eliminated from the landscape small water bodies, rich in sediments and vegetation, and indispensable for the reproduction of amphibians. Some of the water reservoirs, which still have remained in the landscape, dry up before tadpoles go through metamorphosis. This phenomenon is particularly evident in agricultural areas, which until recently had constituted the reservoir of resources for most of our amphibians. Therefore at present, marshy and boggy places, situated in lake basins and oxbow lakes within river valleys, play an important role in the preservation of newts, toads and frogs. Contamination of the environment with chemical substances is yet another cause for the quantitative decline of amphibians, together with the progressing fragmentation of habitats, as well as losses caused by the increased motor traffic on the roads, which are traditional trails of their mating migration (Przystalski \& Willma 2000). It was found that populations of amphibians are conservative in their choice of migration routes and places to lay eggs. This phenomenon, in connection with a small distance of migrations, reduces the ability of local, vanishing populations to re-colonize the area (Blaustein et al. 1994). This is particularly evident in agricultural areas (Berger 1987, 1989).

Shores of lakes, marshy meadows, peat bogs, oxbow lakes together with adjacent bushes and woodlots are biotopes of the grass snake, also known as ringed snake Natrix natrix. The latter name of the species comes from bright orange or yellow spots around the head, which clearly distinguishes it from the venomous viper. The smooth snake Coronella austriaca is a very rare snake species, the occurrence of which was recorded in the nature (forest) reserve „Las Piwnicki” (Andrzejewski 1977). Common European viper Vipera berus occurs in small numbers in the Torun Valley, mainly in waterlogged areas, peat bogs and humid forests. It is the only domestic venomous species, whose bites could be dangerous for sensitive persons. Sand lizard Lacerta agilis is a thermophilic reptile species connected with grasslands. Usually the attention is focused on green males, running nimbly amidst vegetation. Whereas females have camouflage dark brown colour of the body. The sand lizard has two colour forms. The form with typical green and dark brown colours predominates. The form with a cinnamon dorsum L. agilis erythronota occurs much less frequently. Both forms can be encountered on insolated slopes, glades, grassy logging sites and in ruderal places. The sand lizard is an oviparous species, laying eggs in sunlit sand. The viviparous (common) lizard Lacerta vivipara is yet another lizard species that occurs in more humid and shaded habitats. Males and females are similarly coloured. Their dorsa are grey and sides of the body are speckled with light spots. The common lizard is an ovoviviparous species, which means that the development of embryos takes place in the female body and young specimens are born entirely adapted to independent life. Blindworm Anguis fragilis is a common resident in the humid parts of deciduous and mixed pine forests. The species is widespread in the whole area of the Torun Valley.

The unique character of avifauna in the Torun Valley is determined mainly by two large nature-landscape units situated within the Valley - the Lower Vistula Valley and Bydgoszcz Forest. The Lower Vistula Valley constitutes the Special Protection Area for Birds (PLB040003) included in the European network Natura 2000, whereas the forest complex of Bydgoszcz Forest is situated within the Protected Landscape Areas - the Dunes of the TorunBydgoszcz Valley and the Inland Dunes to the south of Toruń.

Great heterogeneity, as well as spatial and temporal dynamics of flood plain habitats of the Vistula River and its channel affect the species richness and the count of birds occurring here. In this area, within the Torun Valley, almost 120 nesting species of birds were recorded and several further species, which use the terrace in the breeding season as a feeding ground (Bagiński et al. 1994; Brauze 2001a, 2003a, 2004, 2005; Brauze \& Zieliński 2005a). Within the whole sanctuary of the Lower Vistula Valley, 18 breeding species were recorded from Appendix I of the Council Directive 79/43/EEC - the so-called Birds Directive (SDF Natura 2000). Despite the Vistula River engineering, carried out mainly in the latter half of the 19th century within the borders of the former Prussian partition, by means of repelling spurs, the riverbed here preserved characteristics similar to natural ones. Sandy islands, which are being developed periodically in spring and summer, are characteristic components of the riverbed. They are the place, where rare species of plovers Charadrius sp. and terns Sterna sp. build their nests. In 2004, along the 126 kilometre section of the Vistula River, from the town of Włocławek to the town of Świecie, 143 breeding pairs of the common tern Sterna hirundo were recorded, as well as 45 breeding pairs of the little tern Sterna albifrons, 39 pairs of the little ringed plover Charadrius dubius and one breeding pair of the ringed plover Charadrius hiaticula (Brauze \& Zieliński 2005a). Except for a breeding colony of the common tern located on a metal barge moored near the city of Bydgoszcz and one pair of the little ringed plover nesting on a sandy peninsula, the other birds were nesting on islands in the riverbed of the Vistula. The biggest threat to bird species connected with this environment are discharges of water from the Włocławek Reservoir in spring and summer, which are flooding the nests with eggs and flightless offspring. It is necessary to develop an operational strategy for a fall stage in the town of Włocławek, in order to include the requirements of birds nesting on sandy islands in the Vistula riverbed. 
In the floodplain of the Vistula River, within the Torun Valley, oxbow lakes are relatively frequent. In general, they are small and shallow water bodies. Considerable fluctuations of the water level in oxbow lakes during a year are the cause of small surface area of littoral rush vegetation and relatively poor submerged vegetation. In the year 2000, 17 breeding species of water and marsh birds were recorded in 58 oxbow lakes with the total area of 41.9 ha, situated in the floodplain of the Vistula River between the town of Włocławek and Solec Kujawski (Brauze 2004). A small number of species, as compared with another water bodies in Poland, was related to small and fluctuating surface area of the water level, the small area of rush vegetation, poorly developed submerged vegetation, small depth of oxbow lakes, the lack of islands and easy access to the shores, which facilitates the penetration by humans and pressure by predators (Brauze 2004). The following were the most numerous species: mallard Anas platyrhynchos, Eurasian coot Fulica atra, reed warbler Acrocephalus scirpaceus, great reed warbler Acrocephalus arundinaceus and sedge warbler Acrocephalus schoenobaenus (Brauze 2003a). The avifauna of oxbow lakes, when compared with other water bodies in the country, was the most similar to avifauna of dam reservoirs. The obvious similarity of these bird communities was related to high fluctuations of the water level, characteristic for both environments, which reduce the occurrence of reedbeds, as well as other potential feeding grounds and places for nest building (Brauze 2003a, 2004).

Floodplains of the Vistula River are characterized by the mosaic of arable lands, extensively used meadows and pasturelands, riverside shrubs and woodlots surrounded by zones of tall herbaceous vegetation. This environment constitutes an important sanctuary for many species of birds, which are rare or threatened with extinction. One of them is barred warbler Sylvia nisoria, the average density of which in the floodplains of the Vistula River, between the towns of Nieszawa and Solec Kujawski, was 1.5 pair per $1 \mathrm{~km}^{2}$ (Brauze 2007) in 1998-2000. The local density of this species, recorded within this area in a riparian osier bed -3.3 pair per 10 ha was one of the highest, so far recorded in Poland (Brauze 2007).

Originally, floodplains of big rivers were covered mainly with riparian mixed forests, the mature form of which covers at present less than $1 \%$ of their former acreage of occurrence (Tomiałojć \& Dyrcz 1993). Riparian forests in our climatic zone, due to the species richness and the count of fauna and flora, are corresponding to rain forests (Tomiałojć \& Dyrcz 1993). The riparian mixed poplar-willow forest Salici-Populetum albae in the reserve „Kępa Bazarowa" within the city of Torun is one of the last fragments of mature riparian forest preserved in Poland. In 1993-1995 and 1998-2000, 56 species of breeding birds were recorded here, which makes up ca. $25 \%$ of all species nesting across the country (Brauze 2005). The average density of birds over the test area (11.4 ha), studied with the cartographic method, came to 136.2 pairs per 10 ha. The comparison of species composition of breeding avifauna in 1956-1961 (Strawiński 1963), as well as in 1993-1995 and 1998-2000 (Brauze 2005) revealed that during both periods the same number of 58 species was nesting in the area of the present-day reserve, and the qualitative similarity between the communities of birds expressed by the Sörensen index amounted to $88.0 \%$ (Brauze 2001b). High constancy of species composition, as well as the specific count among some of the species and ecological groups (low density of blackbird Turdus merula and wood pigeon Columba palumbus, the presence of predators) indicate the considerable stability of environmental conditions in the mature riparian forest and the little influence of the city on the avifauna of the Reserve „Kępa Bazarowa” (Brauze 2001a, 2005).

The Vistula River plays also an important role for birds in the winter period, during which large concentrations of water and marsh birds occur in this area, frequently exceeding 1000 specimens over $10 \mathrm{~km}$ of the river course (Brauze, unpublished materials). Rich and heterogeneous nutritional resources brings about the fact that the channel of the Vistula River is a place where white-tailed eagles Haliaeetus albicilla spend their winters in large numbers. In February 2005 along the 67 kilometre section of the river, between the towns of Włocławek and Solec Kujawski, 54 specimens of this rare eagle species were recorded (Brauze et al. 2005).

A specific feature of the Bydgoszcz Forest is a mosaic of pure pine tree stands, homogeneous in respect of the age and heterogeneous in respect of the size. This type of forest landscape results from silviculture based on clear-cuts (strips and zones), which are then planted with Scots Pine Pinus sylvestris with a small admixture of birch Betula sp. In the south-eastern part of the Bydgoszcz Forest, a little over 70 breeding species have been recorded starting from the 1990s (Brauze 2001a, 2003b; Brauze \& Zieliński 2005b; Brauze \& Podsiad 2007; Brauze, unpublished materials).

Species characteristic of old-growth pine forests are hole-nesting birds - an ecological group of birds nesting in different types of hollows, cracks in broken trees and strips of bark peeling off a tree trunk. For the Bydgoszcz Forest, those were: black woodpecker Dryocopus martius, spotted flycatcher Muscicapa striata, common treecreeper Certhia familiaris and short-toed treecreeper Certhia brachydactyla (Brauze, unpublished materials). In 2008, the stock dove Columba oenas joined the group, which probably began to colonize the forest areas in Bydgoszcz Forest (Brauze, unpublished materials). This pigeon species nests most readily in hollows cut by black woodpecker.

Studies on the breeding avifauna at 40 logging sites (up to 4 years since the trees were planted) with the total area 
of 106.2 ha in the south-eastern part of the Bydgoszcz Forest, revealed 7 bird species nesting with the average density of 12.6 pairs per 10 ha (Brauze 2003b). In this environment, three species of the EU significance were recorded (listed in Annex I of the Council Directive 79/409/EEC) woodlark Lullula arborea -4.9 pairs per 10 ha, red-backed shrike Lanius collurio -0.7 pairs per 10 ha and tawny pipit Anthus campestris - 0.5 pairs per 10 ha. The occurrence of individual species at a felling site is determined not only by the site size, but also by its shape. For instance, the condition for the occurrence of tawny pipit were determined as follows: the minimum width of a logging site - ca. $100 \mathrm{~m}$ and the surface area over 2.5 ha. Logging sites that met only one of the aforementioned conditions were not inhabited by this species (Brauze 2003b).

In August 1992, 2867.8 ha of the forest in the southeastern part of the Bydgoszcz Forest (the current Forest Divisions of Cierpiszewo and Gniewkowo) were consumed by a huge fire. At present, 24 breeding species were recorded at a regenerated burnt site, whose average density along three transects came to 31.9 pairs per $1 \mathrm{~km}$ (pairs/10 ha) (Brauze $\&$ Podsiad 2007). Along all the transects, the following species were recorded: willow warbler Phylloscopus trochilus, chaffinch Fringilla coelebs, skylark Alauda arvensis, bunting Emberiza citrinella, blackbird and woodlark. The breeding avifauna of the burn area is of a transitional character between forest bird communities and bird groupings of extensive open areas (Brauze \& Podsiad 2007).

In the Torun Valley the occurrence of over 50 species of mammals have been recorded.

The order of insectivorous (Insectivora) comprises 5 species. The Eastern European hedgehog Erinaceus concolor and the mole Talpa europaea are commonly known species. Encounters with hedgehogs take place most frequently at dusk in field woodlots and bushes, parks, gardens and orchards, often in the direct vicinity of homesteads. Numerous victims of traffic collisions of this species with vehicles on the roads, also prove the common occurrence of the hedgehog in the valley. The mole is yet another species, the presence of which can be easily confirmed. Characteristic molehills, which are created from the soil forced up from their underground corridors, are encountered most frequently on black earths of meadows, in deciduous forests, gardens and orchards. The subsequent three insectivorous species are species of small body size. The biggest one is the common shrew Sorex araneus, commonly occurring in large numbers among thickets in meadows, along edges of fields, parks and forests. Another shrew - the Eurasian pygmy shrew $S$. minutus is the smallest insectivorous species in Poland and its length (including a tail) reaches ca. $10 \mathrm{~cm}$, and its weight does not exceed 6 grams. The species readily inhabits moist biotopes situated along the shores of water bodies, ditches and channels. It also lives in deciduous and mixed forests, meadows, as well as in gardens and parks. Shrewmice are predators actively hunting the most readily available food. Its main component are insects, and then snails, myriapods, also small specimens of amphibians and mammals. The Eurasian water shrew Neomys fodiens is yet another species associated with shores of water bodies, marshy meadows overgrown with clusters of trees and shrubs, as well as humid forests. The water shrew moves easily in the water with the help of its tail, on the underside of which fringes of stiff hairs form a paddle keel. Snails, insects, small aquatic crustaceans, as well as small amphibians, earthworms and sometimes fish dominate in their food.

The group rich in species are bats. During the reproductive season, at least 11 species occur in the Valley. The common Daubenton's bat Myotis daubentonii can be found hunting insects by the water. Serotine bat Eptesicus serotinus and common pipistrelle Pipistrellus pipistrellus are synanthropic species. The species living mainly in mixed and deciduous forests is Natterer's bat Myotis nattereri, which is known for its ability to hunt spiders by picking them up from a cobweb while flying. The common noctule Nyctalus noctula is one of the biggest bats in Poland, the wingspan of which exceeds $35 \mathrm{~cm}$. It is a typical forest species, which chooses natural hollows, cut by woodpeckers, as its daytime hiding places. Lesser noctule Nyctalus leisleri is a species similar to common noctule, however much smaller and seldom encountered in Poland. It is connected with mixed pine forests. The nearest known location of this species comes from the nature reserve „Las Piwnicki", situated near the city of Torun. In this Reserve, also the reproduction of Barbastella barbastellus was observed. Barbastelle is a species, which hides during the day in cracks of old trees and under the strips of bark peeling off old trees (Kasprzyk, oral information).

In the forests surrounding the city of Torun, on both sides of the Vistula River, there occurs another frequent species from the genus Pipistrellus - Nathusius' Pipistrelle P. nathusi. During the day this bat stays in hollows of birds and their artificial equivalents - nesting boxes. Large reproductive colonies can also be encountered in wooden buildings, particularly near forests.

Also the occurrence of soprano pipistrelle P. pygmaeus was confirmed in the Vistula River valley - a recently described species, the smallest bat in Poland, almost identical with the common pipistrelle. The brown long-eared bat $P$. auritus is a commonly known bat species, which occurs both in forests and in the direct vicinity of man; in summer it lives in attics and in winter - in cellars. It is distinguished by large auricles and until recently it was called the long-eared bat. During the seasonal flights to places where bats spend their winter from September to end October, the parti-coloured bat Vespertilio murinus is regularly encountered. Also the northern bat Eptesicus nilssonii was encountered during that period. This species is frequent in 
the mountains and in northern Europe. During migrations, it search for hiding places in modern buildings, probably recognizing them as an equivalent of mountainous biotope (Kasprzyk, unpublished data).

Basements of forts surrounding the city of Torun are important countrywide places for wintering of bats. The counts conducted since 1989 revealed wintering of eleven species (Chudzińska \& Kasprzyk 1995; Kasprzyk 1997, 1999; Kasprzyk \& Zalewski 1992; Kasprzyk \& Ruczyńska 1998; Kasprzyk et al. 2002). Natterer's bat, Daubenton's Bat, greater mouse-eared bat Myotis myotisspend their winters in the largest numbers. Brown long-eared bat, barbastelle and serotine bat are less abundant. Among the species occasionally encountered in hibernacula, the following should be listed: Brandt's Bat Myotis brandtii, whiskered bat Myotis mystacinus, pond bat Myotis dasycneme (Trendowska 2002), northern bat Eptesicus nilssonii, grey longeared bat Plecotus austriacus (Kasprzyk unpublished) and common pipistrelle (Wyrowińska 2005).

Generally, in the Stronghold of Toruń, between 400 and 650 specimens of bats are being counted during winter censuses. The biggest main forts take the special place among objects selected by bats: Fort IV, V, XIII, XV, together with $150 \mathrm{~mm}$ howitzer battery shelters near the fort XIII and an experimental battery shelter near Poznańska St., were included in the Natura 2000 network as Special Area of Conservation - „Forty in Toruń”. The existence of the sanctuary, without protection of smaller transitional shelters, situated within the whole ring of fortifications around Torun, will not entirely protect the existence of local populations of bats. Protection of reproductive colonies found in buildings is equally significant, as well as creation of new substitute shelters in forests. By putting up boxes for bats, one can help to stop the unfavourable phenomenon consisting in decreasing the number of bats in our immediate surroundings.

From the order of lagomorphs (Lagomorpha), two species occur: the European hare Lepus europaeus and European rabbit Oryctolagus cuniculus. The European hare lives in open areas, such as arable fields, meadows, grazing lands, field bushes and afforested lands. It is a sedentary species, attached to a birthplace. During the last ten years, a progressive decrease in the number of hares has been observed.

The European rabbit chooses xeric biotopes connected with sandy soils in pine forests, parks, field thickets and wastelands along river embankments. Rabbits live in colonies. They mark their territory by numerous burrows, each one with few entries. The population size of rabbits fluctuates a lot due to epidemic, contagious diseases called coccidiosis and myxomatosis. The European hare and the rabbit are on the list of games with a fixed closed season.

Rodents (Rodentia) are represented by the largest number of species. The red squirrel Sciurus vulgaris is a common species, which occurs mainly in deciduous and pine forests, but also in parks. There have been five species recorded from the family microtine Microtidae (rodents with short ears and tails). Two of them - bank vole Clethrionomys glareolus and European pine vole Pitymys subterraneus occur mainly in deciduous and pine forests; and although deciduous forests create the most favourable living conditions for them, they also occur in biotopes of river valleys covered with trees and shrubs, as well as in field thickets growing on baulks, escarpments and roadsides. Another five species live in humid environments or in the direct vicinity of waters. Among rodents, the European beaver Castor fiber is the distinguishing species, restored in the territory of former provinces of Bydgoszcz, Włocławek and Torun at the beginning of the 1970s. Beavers from breeding farms were being settled mainly in landscape parks (Przystalski 2004). Beavers adapted to new environments very easily and were very successful in their reproduction. They spread in the Vistula River valley and began to colonize new areas, inhabiting its whole area. Two species of voles are connected with wetlands, marshy sedge meadows, peat bogs, rushes and alder woods, and thus biotopes characteristic of river valleys: root vole $\mathrm{Mi}$ crotus oeconomus - occurring here in large numbers, and less frequently encountered field vole Microtus agrestis. Whereas, muskrat Ondatra zibethicus and water vole Arvicola terrestris are amphibious rodents inhabiting the shores of quiet, stagnant waters with lush vegetation, situated among meadows and fields, as well as peat bogs. Within the valley area, they occur mainly in the zone of oxbow lakes. While the common vole Microtus arvalis chooses different types of environments, i.e. open areas, such as: fields, meadows, grassy edges of forests, glades and logging sites. It favours crops of lucerne and clover, where it reaches high density. It is the most numerous mammal in Poland, with a sudden increase of its count every 3 or 4 years.

As opposed to microtine Microtidae, species from the family Muridae have well developed ears, sticking out of the fur, and long tails. There occur six species of Muridae in the valley. The harvest mouse Micromys minutus is the smallest among them. The species lives in wet sedge meadows, in thickets with well developed vegetation along the riverbanks and lake shores, as well as in forests, agrocenoses, and in winter - in dwelling houses. Its presence in the field is usually revealed by a round, weaved grass nest, which functions as a shelter for the offspring. Whereas the biggest species among Muridae is the infamous common rat Rattus norvegicus, attached to dwelling houses. Moreover, it lives in wet areas, adjacent to waters. It is a species living in colonies.

Also the house mouse Mus musculus is a synanthropic species. In autumn and winter, it usually lives near dwelling houses, and in spring and summer, it moves to baulks, 
meadows, arable fields and gardens, where it stays until the first frost. Another two species - wood mouse Apodemus sylvaticus and yellow-necked mouse Apodemus flavicollis occur mainly in forest areas, although they can also be encountered in parks, gardens, thickets along baulks, escarpments along field tracks and in fields, whereas in winter, e.g. yellow-necked mouse in buildings. The striped field mouse Apodemus agrariusis the last species of the described family that inhabits edges of forests, meadows, arable fields, wet thickets, shores of waters, baulks, gardens and parks. In autumn, it migrates to buildings, barns and stacks. Part of the mouse field population is permanently connected with urban environments, where it formed a new ecotype adapted to life in an urban physiocoenosis (Andrzejewski et al. 1978; Babińska-Werka et al. 1979). When compared with specimens from the populations living in open areas, the urban striped field mice reach a higher body weight.

The order of carnivorans (Carnivora) comprises 11 species. The red fox Vulpes vulpes is the most common canid species (the family of Canidae). It lives in forests, fields and meadows; almost evenly distributed in the whole Valley. The grey wolf Canis lupus takes a special place among predatory mammals living in the valley. Records of wolf reproduction come from the area of Olek (the Forest Division of Dobrzejewice), from 1983, 1985 and 1986 (Andrzejewski \& Wołk 1991). As indicated by the latest observations, grey wolves can still find their refuge (Wilczy Kąt and Zielona Kępa) in the Forest Division of Dobrzejewice and in Bydgoszcz Forests. Another species - raccoon dog Nyctereutes procyonoides is an undesirable adventive species from the east, colonizing the valley. The family of mustelids (Mustelidae) is represented in the described area by 8 species. The biggest of them is European badger Meles meles - a rather rare species occurring in forests adjacent to fields and meadows. Otter Lutra lutra is a species that lives in rivers, lakes and fish ponds. The Valley of the Vistula River is a natural corridor through which this species spreads in Poland (Brzeziński 1995). The genus of Martes is represented by pine marten Martes martes, associated with larger forest complexes, as well as by stone marten $M$. foina, which inhabits margins of open forests, parks, the immediate vicinity of farmsteads and church steeples. The genus of Mustela is represented by the European polecat Mustela putorius, which is encountered in riverine forests, as well as in open forest areas adjacent to meadows and fields, and in winter - also in outbuildings. Stoat $M$. erminea is a species that seldom occurs; and margins of deciduous and mixed forests, as well as valleys of rivulets, ruins and old parks are primary environments of this species. Least weasel M. nivalis is the smallest species among mustelids. During the reproductive season it inhabits margins of forests, fields, meadows, baulks, parks and graveyards, whereas in winter, it migrates to buildings in housing estates. During the last twenty years, American mink $M$. vison has become a new species in the valley. Specimens of this species are descendants of fugitives from breeding farms, which through the process of adaptation to local lowland conditions developed a feral, expansive population. They inhabit overgrown shores of lentic and lotic waters. It is a species that drives away the muskrat.

From the order of even-toed ungulates (Artiodactyla), the common European elk Alces alces is the species of the largest body size. It occurs in Forest Inspectorate of Dobrzejewice. The forests of the valley are inhabited by a relatively common species in this area - the red deer Cervus elaphus. Also the roe deer Capreolus capreolus is a common species. In the Torun valley, its two ecotypes occur: the field one - found in agrocenoses with some clusters of trees and shrubs, as well as the forest one, which lives in extensive Bydgoszcz Forests. Another species of cervids - fallow deer Dama dama, is an introduced species with great adaptation abilities. It occurs in open forests and at their margins. Also farmlands and meadows, adjacent to forests, are feeding grounds of this species. In the humid parts of deciduous and mixed forests, the wild boar Sus scrofa occurs. It is a valuable species of forest ecosystems. Wild boars rooting for food scarify the surface soil layers and mix them with litter. Wild boars significantly reduce the amount of larvae and pupae of insects, including many species classified as forest pests. Wild boars can cause some considerable damage in agrocenoses located near forests.

\section{Conclusions}

Being a mosaic of miscellaneous habitats, the Torun Valley is a refuge for numerous species who find their shelter here, food and favourable conditions for reproduction. It is an important natural corridor for animals migrating across the country. Most of the vertebrate species occurring in the ecosystems of the Torun Valley are legally protected; a considerable number of species are rare and endangered with extinction. The Special Area of Conservation Natura 2000 - „Forts in Torun” - plays a significant role in the protection of bats. The area comprises four Prussian forts of the former Stronghold of Torun. Certain fragments of the valley, which form the Special Protection Area Natura 2000 - the Lower Vistula Valley - are important for protection of aquatic animals and plants. Despite the fact that conservation areas were created in the described area, there are quite a lot threats posed by urbanization and municipal services management. Moreover, the dam in the town of Włocławek, located upstream of the Vistula River and upstream from the city of Toruń, constitutes a barrier limiting the migration of aquatic animals. 


\section{References}

Andrzejewski H., 1977, Płazy i gady rezerwatu „Las Piwnicki" koło Torunia [Amphibians and reptiles of reserve „Las Piwnicki” near Toruń], Acta Universitatis Nicolai Copernici, Biologia 19, Nauki Mat.-Przyr. 30: 159-174.

Andrzejewski R., Babińska-Werka J., Gliwicz J. \& Goszczyński J., 1978, Synurbisation processes in population of Apodemus agrarius. I. Characteristics of populations in urbanization gradient, Acta theriologica 23: $341-351$.

Andrzejewski H. \& Wołk K., 1991, Wilk Canis lupus L. w okolicach Torunia [Wolf Canis lupus L. in the neighbourhood of Toruń], Przegląd Zoologiczny 35 (3-4): 398-396.

Babińska-Werka J., Gliwicz J. \& Goszczyński J., 1979, Synurbization processes in a population of Apodemus agrarius. II. Habitats of the striped field mouse in town, Acta Theriologica 24: 405-415.

Backiel T., 1993, Ichtiofauna dużych rzek - trendy i możliwości ochrony [Ichthyofauna of major rivers trends and opportunities to protect], [in:] L. Tomiałojć (ed.), Ochrona przyrody i środowiska w dolinach nizinnych rzek Polski [Environmental protection and conservation in the lowland valleys of the Polish rivers], Instytut Ochrony Przyrody PAN, Kraków: 39-48.

Bagiński W., Brauze T. \& Zieliński J., 1994, Rozpoznanie awifaunistyczne doliny Wisły między Solcem Kujawskim a Świeciem na terenach zalewowych w granicach województwa bydgoskiego [Recognition of avifauna of the Vistula River valley between Solec Kujawski and Świecie on the flood plains within the province of Bydgoszcz], Urząd Wojewódzki, manuscript, Bydgoszcz.

Bartel R., 2001, Return of salmon back to Polish waters, Ecohydrol. Hydrobiol. 1(3): 377-392.

Bartel R., Chełkowski Z. \& Sych R., 1984, Le saumon en Polonge, Saumons 49: 4-6.

Berger L., 1987, Impact of agriculture intensification on Amphibia, [in:] J. J. van Gelder, H. Strijbosch, P. J. M. Bergers (eds.), Proceedings of the 4th Ordinary General Meeting of the Societas Europaea Herpetologica, University of Nijmegen, Faculty of Sciences, Nijmengen: 79-82.

Berger L., 1989, Disapperance of amphibian larvae in the agricultural landscape, Ecology International Bulletin: 17: $65-73$.

Blaustein A. R., Wake D. B. \& Sousa W. P., 1994, Amphibian declines - judging stability, persistence, and susceptibility of populations to local and global extinctions, Conservation Biology 8(1): 60-71.

Brauze T., 2001a, Struktura przestrzenna zespołów ptaków lęgowych środowisk terasy zalewowej Wisły pomiędzy Włocławkiem a Solcem Kujawskim [The spatial struc- ture of breeding birds communities of flood terrace of the Vistula River between Włocławek and Solec Kujawski], Doctoral Thesis, manuscript, UMK, Torun.

Brauze T., 2001b, Zmiany w składzie gatunkowym awifauny lęgowej rezerwatu „Kępa Bazarowa” badanej w latach 1956-1961 i 1993-1995 [Changes of species composition of breeding avifauna in „Kępa Bazarowa” reserve (Toruń)], [in:] P. Indykiewicz, T. Bartczak, G. Kaczorowski (eds.) Bioróżnorodność i ekologia populacji zwierzęcych w środowiskach zurbanizowanych [Biodiversity and ecology of animal populations in urban environments], NICE, Bydgoszcz: 206-208.

Brauze T., 2003a, Wodno-błotna awifauna lęgowa starorzeczy na terasie zalewowej Wisły między Solcem Kujawskim a Ciechocinkiem [Breeding waterbirds of oxbow lakes on the flood terrace of the Vistula River between Solec Kujawski and Ciechocinek], [in:] A. Przystalski, B. Wilczyńska (eds.), Zoologia na progu XXI wieku, Mat. Ogólnopolskiego Zjazdu Sekcji Ornitol. PTZool. [Zoology at the beginning of the 21st century, Materials from the Convention of the Ornithological Section of the Polish Zoological Society], UMK, Toruń: 95.

Brauze T., 2003b, Awifauna lęgowa zrębów południowowschodniej części Puszczy Bydgoskiej [Breeding avifauna of clear cutting areas in north-east part of Bydgoszcz Forest], [in:] A. Przystalski, B. Wilczyńska (eds.), Zoologia na progu XXI wieku, Mat. Ogólnopolskiego Zjazdu Sekcji Ornitol. PTZool. [Zoology at the beginning of the 21 st century, Materials from the Convention of the Ornithological Section of the Polish Zoological Society], UMK, Toruń: 96.

Brauze T., 2004, Species diversity of breeding waterbirds of oxbow lakes on the flood terrace of the Vistula River between Ciechocinek and Solec Kujawski, Zoologica Poloniae 49(1-4): 211-218.

Brauze T., 2005, Awifauna lęgowa dojrzałego łęgu wierzbowo-topolowego w rezerwacie „Kępa Bazarowa” w Toruniu [Breeding avifauna of mature willow-poplar forest in „Kępa Bazarowa” reserve in Toruń], Przegląd Zoologiczny 49: 95-105.

Brauze T., 2007, Liczebność i preferencje środowiskowe jarzębatki Sylvia nisoria na terasie zalewowej dolnej Wisły [Numbers and habitat preferences of the Barred Warbler Sylvia nisoria on the floodplain terrace of the lower Vistula River], Notatki Ornitologiczne 48: $1-10$.

Brauze T., Łukasik D., Neubauer G., Zagalska-Neubauer M. \& Zieliński J., 2005, Zimowanie bielika Haliaeetus alibicilla na podtoruńskim odcinku Wisły w latach 2003/2004 oraz 2004/2005 [Wintering of White-tailed Eagle on the section of Vistula River near Torun in the years 2003/2004 and 2004/2005], [in:] J. J. Nowakowski (ed.), Ornitologia polska na progu XXI stulecia dokonania i perspektywy, Mat. Zjazdu Sekcji Ornitol. 
PTZool. [Polish ornithology at the beginning of the 21st century - accomplishments and perspectives, Materials from the Convention of the Ornithological Section of the Polish Zoological Society], UWM, Olsztyn: 159.

Brauze T. \& Podsiad M., 2007, Awifauna lęgowa obszarów leśnych po 13 latach od wielkiego pożaru w południowo-wschodniej części Puszczy Bydgoskiej [Breeding avifauna of woodland areas after 13 years from great conflagration in the north-east part of Bydgoszcz Forest], [in:] E. Biesiadka, J. J. Nowakowski (eds.), Zmienność - Adaptacja - Ewolucja, Mat. Ogólnopolskiego Kongresu Zoologicznego [Variability - Adaptation - Evolution, Materials from the Polish Zoological Congress], UMW, Olsztyn: 114.

Brauze T. \& Zieliński J., 2005a, Liczebność ptaków wodnych i błotnych na odcinku rzeki Wisły między Włocławkiem a Świeciem podczas spływów przeprowadzonych wiosną 2004 roku [Number of waterbirds in the Vistula River between Włocławek and Świecie during spring boat rallies in 2004], [in:] J. J. Nowakowski (ed.), Ornitologia polska na progu XXI stulecia - dokonania i perspektywy, Mat. Zjazdu Sekcji Ornitol. PTZool. [Polish ornithology at the beginning of the 21 st century - accomplishments and perspectives, Materials from the Convention of the Ornithological Section of the Polish Zoological Society], UWM, Olsztyn: 215-216.

Brauze T. \& Zieliński J., 2005b, Wpływ linii kolejowych na leśną awifaunę lęgową [Influence of railway line on forest breeding avifauna], [in:] J. J. Nowakowski (ed.), Ornitologia polska na progu XXI stulecia - dokonania i perspektywy, Mat. Zjazdu Sekcji Ornitol. PTZool. [Polish ornithology at the beginning of the 21st century - accomplishments and perspectives, Materials from the Convention of the Ornithological Section of the Polish Zoological Society], UWM, Olsztyn: 217-218.

Brzeziński M., 1995, Występowanie wydry. Mapa nr 9 [Occurrence of otter. Map No. 9], [in:] A. Liro (ed.), Koncepcja krajowej sieci ekologicznej ECONET Polska [Concept of the National Ecological Network ECONET-Poland], Fundacja IUCN Poland, Warszawa.

Council Directive 79/43/EEC of 21 May 1992 on the Conservation of natural habitats and wild fauna and flora, The Council of the European Communities, Brussels. (http://eur-lex.europa.eu/LexUrlServ/LexUriServ.do? uri= CELEX:31992 L0043: HTML

Council Directive 79/409/EEC of 2 April 1979 on the Conservation of Wild Birds, The Council of the European Communities, Brussels.(http://eur-lex. europa. Eu / Lex UrlServ /LexUriServ.do? uri = CELEX:31978 L0409:EN:HTML)

Chudzińska I. \& Kasprzyk K., 1995, Nietoperze hibernujące w fortach Torunia [The bats hibernating in Torun forts], Biuletyn CIC 18/19: 15-16.
Chylarecki P., Bukaciński D., Dombrowski A. \& Nowicki W., 1995, IV. Awifauna [IV. Avifauna], [in:] E. Gacka-Grzesikiewicz (ed.), Korytarz ekologiczny doliny Wisły. Stan - funkcjonowanie - zagrożenia [Vistula as an Ecological Corridor. State - Functioning - Threats], Fundacja IUCN Poland, Warszawa.

Danilkiewicz Z., 1996, Babka łysa (gołogłowa), Neogobius gymnotrachelus (Kessler, 1857) (Perciformes, Gobiidae) - nowy, gatunek w ichtiofaunie zlewiska Morza Bałtyckiego [Round goby, Neogobius melanostomus (Kessler, 1857) (Perciformes, Gobiidae) - a new species to the ichthyofauna of the Baltic Sea basin], Kom. Ryb. IRS 2: 27-29.

Danilkiewicz Z., 1998, Babka szczupła, Neogobius fluviatilis (Pallas, 1811), Perciformes, Gobiidae - nowy, pontyjski element w ichtiofaunie zlewiska Morza Bałtyckiego [Round goby Neogobius fluviatilis (Pallas, 1811), Perciformes, Gobiidae - new Pontic element to the ichthyofauna of the Baltic Sea basin], Fragmenta Faunistica 41: 269-277.

Gacka-Grzesikiewicz E. (ed.), 1995, Korytarz ekologiczny doliny Wisły. Stan - funkcjonowanie - zagrożenia [Vistula as an Ecological Corridor. State - Functioning Threats], Fundacja IUCN Poland, Warszawa.

Głowaciński Z. (ed.), 2001, Polska czerwona księga zwierząt. Kręgowce [Polish red book data of animals, Vertebrates], PWRiL, Warszawa.

Grabda E., 1968, Jesiotr ryba ginąca [Sturgeon - disappearing fish], Ochrona Przyrody 33: 177-191.

Jokiel J. \& Bartel R., 1983, A historical record based on tagging the Vistula salmon which has already been extinct, ICES, CM, M, 17.

Kajak Z., 1993, Stan i potrzeby ochrony Wisły i jej doliny [The Vistula River and its valley: the present state and conservation needs], [in:] L. Tomiałojć (ed.) Ochrona przyrody i środowiska $w$ dolinach nizinnych rzek Polski [Nature and environment conservation in the lowland river valleys of Poland], Instytut Ochrony Przyrody PAN, Kraków: 69-80.

Kakareko T., 1999, Perccottus gleni Dybowski, 1877 (Odontobutidae) w Zbiorniku Włocławskim na dolnej Wiśle [Perccottus gleni Dybowski, 1877 (Odontobutidae) in Włocławski Dam Reservoir o the lower Vistula River], Przegląd Zoologiczny 43(1-2): 107-110.

Kasprzyk K., 1997, Fauna nietoperzy Polski Północno-Wschodniej - aktualny stan wiedzy [Bat fauna of the north-east Poland - Current state of knowledge], Acta Universitatis Nicolai Copernici, Biologia 53: 60-87.

Kasprzyk K., 1999, W świecie nietoperzy [In the world of bats], [in:] A. Urbański, L. Kotlewski (eds.), Informator Przyrodniczy [Nature Guide] 8: 19-23.

Kasprzyk K. \& Ruczyńska I., 1998, Koncepcja ochrony nietoperzy zimujących w obiektach Twierdzy Toruń [Concept of conservation wintering bats in Torun For- 
tress], [in:] L. Narębski (ed.), Twierdza Toruń - stan badań i problematyka konserwatorska [Torun Fortress - state of research and conservation problems], Materiały z konferencji naukowej zorganizowanej przez Towarzystwo Przyjaciół Fortyfikacji i Generalnego Konserwatora Zabytków, Toruń 1997, Agencja Wydawnicza Zebra Sp. z o.o., Warszawa-Kraków: 151-156.

Kasprzyk K., Ruczyńska I. \& Wojciechowski M., 2002, Zimowy spis nietoperzy na Pomorzu Nadwiślańskim w latach 1996-1999 [Winter bat census in the Pomorze Nadwiślańskie in 1966-1999], Nietoperze 3(1): 39-52.

Kasprzyk K. \& Zalewski A., 1992, Drobne ssaki okolic Torunia [Small mammals of the surrounding of Toruń], Przegląd Zoologiczny 36(1-4): 211-217.

Przystalski A., 2000, Avifauna and herpetofauna of the Wistula valley between Włocławek and Toruń, Acta Univ. Nicolai Copernici, Prace Limnologiczne 21, Nauki Mat.-Przyr., 105: 107-117.

Przystalski A., 2004, Kręgowce województwa kujawsko-pomorskiego [Vertebrates of Kujawsko-Pomorskie province], [in:] M. Dąbrowski, K. Leszczyńska-Deja, M. Machnikowski, P. Smoleński (eds.), Raport o stanie przyrody województwa kujawsko-pomorskiego, Kujawsko-Pomorski Urząd Wojewódzki, Wojewódzki Konserwator Przyrody: 83-94. [Report on the state of nature of Kujawsko-Pomorskie province,the Provincial Office of Kujawy and Pomerania, the Provincial Nature Conservation Officer]. NICE, Bydgoszcz.

Przystalski A. \& Willma B., 2000, Wpływ konstrukcji autostrad na płazy [Impact of highway construction on Amphibians], [in:] Biologia płazów i gadów. Materiały z V Ogólnopolskiej Konferencji Herpetologicznej [Biology of amphibians and reptiles. Materials from the 5th Polish Herpetological Conference], WNAP, Kraków: 93-95.

Przystalski A. \& Kasprzyk K., 1997, IV. Kręgowce - Vertebrata, [in:] L. Rutkowski (ed.), Czerwona lista roślin i zwierząt Pomorza i Kujaw [Red list of endangered plants and animals of Kujavian-Pomeranian Region], Acta Universitati, Nicolai Copernici, Biologia, Nauki Mat.-Przyr. 53: 25-32.

Strawiński S., 1963, Ptaki podmiejskich zadrzewień Torunia [Birds of suburban shelterbelts of Toruń], Stud. Soc. Sc. Tor., Sec. Zool. 7(5): 1-25.

Tomiałojć L. (ed.), 1993, Ochrona przyrody i środowiska w dolinach nizinnych rzek Polski [Nature and environment conservation in the lowland river valleys of Poland], Instytut Ochrony Przyrody PAN, Kraków.

Tomiałojć L. \& Dyrcz A., 1993, Przyrodnicza wartość dużych rzek i ich dolin w Polsce w świetle badań ornitologicznych [Nature conservation in large river valleys of Poland: an ornithological outlook], [in:] L. Tomiałojć (ed.), Ochrona przyrody i środowiska w dolinach nizinnych rzek Polski [Nature and environment conservation in the lowland river valleys of Poland], Wyd. IOP PAN, Kraków: 11-36.

Trendowska J., 2002, Twierdza Fortowa w Toruniu miejscem hibernacji nietoperzy [Toruń Fortress as a hibernation place of bats], Master Thesis, manuscript, Zakład Zoologii Kręgowców UMK, Toruń.

Wyrowińska M., 2005, Nietoperze zimujące w fortach toruńskich - Specjalnym Obszarze Ochrony sieci Natura 2000 [Hibernating bats in the forts of Torun Special Protection Area, Natura 2000 network], Master Thesis, manuscript, Zakład Zoologii Kręgowców UMK, Toruń.

Żarnecki S., 1963, Occurence of seasonal population in Atlantic salmon (Salmo salar L.) and sea trout (Salmo trutta L.) in the Vistula River, Acta Hydrobiol. 5: 255-294.

Żarnecki S., 1964, Times of entering the Vistula by summer and winter forms of salmon and sea trout in an anual cycle 1952, Acta Hydrobiol. 6: 255-267.

Żelechowska J., 1964, Jesiotr w Wiśle koło Torunia [Sturgeon in the Vistula near Toruń], Gosp. Ryb. 8: 6-7. 